\title{
Chlorella for protein and biofuels: from strain selection to outdoor cultivation in a Green Wall Panel photobioreactor
}

\author{
Alessia Guccione ${ }^{1}$, Natascia Biondi ${ }^{1}$, Giacomo Sampietro ${ }^{1}$, Liliana Rodolfi ${ }^{1}{ }^{2}$, Niccolò Bassi $^{2}$ and Mario R Tredici ${ }^{\text {* }}$
}

\begin{abstract}
Background: Chlorella is one of the few microalgae employed for human consumption. It typically has a high protein content, but it can also accumulate high amounts of lipids or carbohydrates under stress conditions and, for this reason, it is of interest in the production of biofuels. High production costs and energy consumption are associated with its cultivation. This work describes a strategy to reduce costs and environmental impact of Chlorella biomass production for food, biofuels and other applications.

Results: The growth of four Chlorella strains, selected after a laboratory screening, was investigated outdoors in a low-cost $0.25 \mathrm{~m}^{2}$ GWP-II photobioreactor. The capacity of the selected strains to grow at high temperature was tested. On the basis of these results, in the nitrogen starvation trials the culture was cooled only when the temperature exceeded $40^{\circ} \mathrm{C}$ to allow for significant energy savings, and performed in a seawater-based medium to reduce the freshwater footprint. Under nutrient sufficiency, strain $\mathrm{CH} 2$ was the most productive. In all the strains, nitrogen starvation strongly reduced productivity, depressed protein and induced accumulation of carbohydrate (about 50\%) in strains F\&M-M49 and IAM C-212, and lipid (40 - 45\%) in strains PROD1 and CH2. Starved cultures achieved high storage product productivities: $0.12 \mathrm{~g} \mathrm{~L}^{-1} \mathrm{~d}^{-1}$ of lipids for $\mathrm{CH} 2$ and $0.19 \mathrm{~g} \mathrm{~L}^{-1} \mathrm{~d}^{-1}$ of carbohydrates for F\&M-M49. When extrapolated to large-scale in central Italy, $\mathrm{CH} 2$ showed a potential productivity of $41 \mathrm{tha}^{-1} \mathrm{y}^{-1}$ for biomass, $16 \mathrm{t} \mathrm{ha}^{-1} \mathrm{y}^{-1}$ for protein and $11 \mathrm{t} \mathrm{ha}^{-1} \mathrm{y}^{-1}$ for lipid under nutrient sufficiency, and $8 \mathrm{t} \mathrm{ha} \mathrm{a}^{-1} \mathrm{y}^{-1}$ for lipid under nitrogen starvation.

Conclusions: The environmental and economic sustainability of Chlorella production was enhanced by growing the organisms in a seawater-based medium, so as not to compete with crops for freshwater, and at high temperatures, so as to reduce energy consumption for cooling. All the four selected strains are good candidates for food or biofuels production in lands unsuitable for conventional agriculture. Chlorella strain $\mathrm{CH} 2$ has the potential for more than 80 tonnes of biomass, 32 tonnes of protein and 22 tonnes of lipid per year under favourable climates.
\end{abstract}

Keywords: Chlorella, Outdoor cultivation, Food, Thermotolerance, Nitrogen starvation, Sustainability, GWP-Il, Biofuel

\section{Background}

Chlorella (Chlorophyta, Trebouxiophyceae), one of the most studied microalgae, is commercially cultivated by more than 70 companies in the world [1]. The annual production of Chlorella biomass exceeds 2,000 tonnes $[1,2]$, mostly used for dietary supplements and nutraceuticals, with a minor share destined to the cosmetic market and aquaculture [1]. Chlorella is commercially

\footnotetext{
*Correspondence: mario.tredici@unifi.it

'Dipartimento di Scienze delle Produzioni Agroalimentari e dell'Ambiente Sezione di Microbiologia Agraria, Università degli Studi di Firenze, Piazzale delle Cascine 24, Firenze 50144, Italy

Full list of author information is available at the end of the article
}

produced under photoautotrophic conditions, mainly in open ponds (both raceway and circular) [3,4], or heterotrophically in fermenters [4]. The largest closed system used for autotrophic production at commercial scale is the $700 \mathrm{~m}^{3}$ tubular photobioreactor operated by Roquette Klötze GmbH \& Co. KG (Klötze, Germany), which produces annually about 100 tonnes of high quality Chlorella biomass for the health food market [5].

When molecular data became available it was clear that different green microalgae with similar morphophysiological characters had been classified as 'Chlorella'. The taxonomy of the genus is still under revision [6]. C. vulgaris and C. pyrenoidosa are the two most cultivated 
at commercial scale. The latter species still has an uncertain taxonomic collocation [6,7]. Chlorella thrives in fresh or brackish waters, but several marine strains are also known. In this respect, it is important to avoid confusion with the so-called 'marine chlorella', a much researched organism in the 1980s because of its high eicosapentaenoic acid (EPA) content, which was later correctly identified as Nannochloropsis sp. [8].

Chlorella is one of the few microalgae (together with Dunaliella, Haematococcus and Arthrospira) largely employed for human consumption. It has a high protein content with a balanced amino acid composition $[9,10]$, besides a good content of vitamins, minerals, pigments [10] and short-chain polyunsaturated fatty acids, including oleic and linoleic acids $[11,12]$. Some strains are also a good source of lutein [13]. Chlorella is recognized as a safe food ingredient worldwide [14,15], mainly due to its long history of human consumption as a food supplement and nutraceutical $[7,9,16,17]$. In vivo studies on its potential as food and protein source have been carried out mainly in the past $[18,19]$, when legislation concerning trials on people was less restrictive [18]. More recently, Chlorella biomass has been proposed as a food ingredient: as colouring agent for traditional butter cookies [20], as additive for fermented milk and yoghurt to enhance the viability of bacterial probiotics $[21,22]$ and incorporated in pasta products to increase their nutritional quality [23]. A Chlorella protein hydrolysate has also been tested as a food additive [24]. The food and feed markets require large quantities of biomass produced at low cost (less than $1 € \mathrm{~kg}^{-1}$ ) [25]. Currently, algae production costs are higher than $4-5 € \mathrm{~kg}^{-1}$ and, although recent economic analyses foresee a decrease to $1-2 € \mathrm{~kg}^{-1}$ [26], the commercialization of Chlorella as a food commodity is not mature yet.

High production costs are also the main limitation to another potential application of this microalga: biofuel production. In the last decade, algal biofuels have received a great deal of attention [27]. Chlorella is among the algae of major interest for biofuels, since under stress and depending on the strain, it can accumulate large amounts of lipids [28] or synthesize starch $[29,30]$. Research carried out under nitrogen or phosphorus starvation has shown significant lipid accumulation (up to about 50\%) and high lipid productivities $[31,32]$. Studies have also been carried out under nutrient replete conditions. Moheimani cultivated Chlorella sp. in a $120 \mathrm{~L}$ bag photobioreactor, obtaining a biomass productivity during summer of up to $0.28 \mathrm{~g} \mathrm{~L}^{-1} \mathrm{~d}^{-1}$ and a lipid content of about 25\% [33]. Pribyl et al., with Chlorella vulgaris in a $150 \mathrm{~L}, 6.6 \mathrm{~m}^{2}$ thin-layer open system, obtained maximum biomass and lipid productivities of 1.26 and $0.33 \mathrm{~g} \mathrm{~L}^{-1} \mathrm{~d}^{-1}$, respectively [34]. Some Chlorella are also highly productive in starch, and thus potential substitutes of starch-rich terrestrial plants for bioethanol production. Brányiková et al. increased starch content of Chlorella up to $50 \%$ by applying sulfur limitation in an outdoor thin-layer open system [35].

The extracted (delipidated) Chlorella biomass, still rich in proteins, carbohydrates, minerals and bioactive compounds, could provide raw materials for feed and food applications [36,37]. This is important in view of recent analyses that have shown that to achieve a positive energy balance and produce economically viable biofuels, the residue after extraction must be used for co-products [38-40]. A different approach, which seems more practical and feasible, is targeting feed, food or chemicals as the first product. After the extraction of the valuable compound, recovery of the residual energy (and nutrients) of the spent biomass by alcoholic fermentation or anaerobic digestion could be carried out. Integrating food and fuel production processes, besides providing economic advantages, would lead to a higher environmental sustainability $[41,42]$. However, the issue of matching markets of different sizes, such as that of biofuels and high-value products, must be considered.

Microalgae have several advantages over traditional crops. Their cultivation does not need fertile soil and they are very efficient in using nutrients, thus avoiding or limiting pollution of water bodies by unused fertilizers. Some algae can be cultivated in brackish, saline or seawater, thus they do not compete for dwindling freshwater resources. The use of wastewaters as a nutrient source is also an attractive possibility that can be considered when biofuels are the target. Microalgae cultures can be fed with $\mathrm{CO}_{2}$ from flue gases [42-46]; however, the need to supply $\mathrm{CO}_{2}$ to the culture should be seen as a limitation, compared to plants that absorb $\mathrm{CO}_{2}$ directly from the air, rather than an advantage. To make microalgal biomass economically competitive and sustainable, either for food or biofuels, the cost of the culture system, as well as operational costs, must be significantly reduced $[44,45]$. In particular, mixing $[26,44,45,47,48]$ and cooling $[44,45,47]$ costs, which are very high in closed systems, need to be cut substantially by, for example, selecting strains with high buoyancy and able to grow at high temperatures [49,50]. For sustainable microalgae cultivation, strains able to grow with high productivity in seawater or brackish water are required.

The aim of this work was to evaluate the performance (in terms of protein, carbohydrate and lipid content and productivity) of selected Chlorella strains grown under conditions devised to reduce operational costs and increase the sustainability of the cultivation process. To reach this goal, outdoor growth experiments with four strains, selected after a thorough laboratory screening, were carried out in a low-cost photobioreactor, the Green Wall Panel (GWP), with reduced or without cooling in a 
seawater-based, instead of the standard freshwater-based, culture medium. Cultivation in nitrogen deprived media was finally tested to increase storage product accumulation (lipid or carbohydrate) and evaluate the potential of the selected strains for biofuel (biodiesel or ethanol) production.

\section{Results}

Laboratory screening of nine Chlorella strains

Nine Chlorella strains were cultivated in $300 \mathrm{~mL}$ bubble tubes in the laboratory to evaluate their productivity and biochemical composition in nutrient sufficient and nitrogen deprived growth media. Under nutrient sufficiency, batch and semi-continuous cultures were compared. With two exceptions (IRT2 and CH2), batch cultures achieved higher productivities (on average 0.68 versus $0.55 \mathrm{~g} \mathrm{~L}^{-1} \mathrm{~d}^{-1}$ ). The more productive batch cultures were those of strains MACH1, CH2, PROD1, IAM C-212 and PAVV2P2, all above $0.7 \mathrm{~g} \mathrm{~L}^{-1} \mathrm{~d}^{-1}$. In semi-continuous culture, only strain $\mathrm{CH} 2$ attained a high productivity $\left(0.82 \mathrm{~g} \mathrm{~L}^{-1} \mathrm{~d}^{-1}\right)$ (Table 1$)$. Under nitrogen starvation (evaluated only in batch), the average biomass productivity decreased from 0.68 to $0.37 \mathrm{~g} \mathrm{~L}^{-1} \mathrm{~d}^{-1}$. The decrease, observed for all the strains, ranged from a minimum of $31 \%$ for $\mathrm{MACH} 1$ to a maximum of $75 \%$ for IAM C-212 (Table 1).

The biochemical composition of biomasses harvested at the end of the experiment from batch cultures is shown in Table 2. With the exception of one strain (BdR3), under nutrient sufficiency, biomasses showed a good protein content (about 40\%). Carbohydrates varied from a minimum of $24.2 \%$ for F\&M-M49 to a maximum of $35.6 \%$ for BdR3, while lipids ranged from $20.0 \%$ for PAVV2P2 to $28.1 \%$ for PROD1. Under nitrogen deprivation the protein content decreased substantially in all the strains (on average to about 25\%), three strains (CCAP 211-11b, PROD1 and $\mathrm{CH} 2$ ) accumulated lipids up to more than $45 \%$ and the other six accumulated carbohydrate up to about $50 \%$. No strain accumulated both carbohydrate and lipids. The highest lipid productivity was obtained with strains $\mathrm{CH} 2$ and PROD1. The highest carbohydrate productivity was attained by strains IAM C-212 and F\&M-M49 (data not shown).

A second laboratory trial was carried out with the nine Chlorella strains to compare growth in freshwater- and seawater-based media and test their ability to grow when the culture temperature was maintained, during the light hours, at $40^{\circ} \mathrm{C}$, a value easily reached during outdoor cultivation in closed systems when cooling is not applied. Three strains (PAVV2P2, CCAP 211-11b and PROD1) did not survive exposure to these high temperatures (Table 3). Four strains (F\&M-M49, IAM C-212, MACH1 and CH2) showed higher productivities when cultured for 8 hours a day at $40^{\circ} \mathrm{C}$, with respect to continuous cultivation at $25^{\circ} \mathrm{C}$. The best performance at high temperature was obtained by $\mathrm{CH} 2$ (with a productivity of $1 \mathrm{~g} \mathrm{~L}^{-1} \mathrm{~d}^{-1}$ ), followed by IAM C-212 (0.80 $\left.\mathrm{g} \mathrm{L}^{-1} \mathrm{~d}^{-1}\right)$, MACH1 (0.69 $\left.\mathrm{g} \mathrm{L}^{-1} \mathrm{~d}^{-1}\right)$ and F\&M-M49 $\left(0.57 \mathrm{~g} \mathrm{~L}^{-1} \mathrm{~d}^{-1}\right)$. In the seawater-based F medium all the nine strains grew well, and strains $\mathrm{CH} 2$, isolated from seawater, PROD1 and IRT2 achieved higher productivities compared to the freshwater-based BG11 medium (Table 3).

From the laboratory screening four Chlorella strains (IAM C-212, PROD1, F\&M-M49 and CH2) emerged as promising for sustainable biomass and energy feedstock production, and were selected for further study. The main selection criteria were productivity, capacity to grow in a seawater-based medium and at high temperatures, and type of storage product accumulated under nitrogen starvation. The four selected strains were evaluated outdoors, first in $1 \mathrm{~L}$ bubble tubes and then in $0.25 \mathrm{~m}^{2}$ GWP-II reactors.

\section{Outdoor cultivation of four selected Chlorella strains without temperature control in bubble tubes and in $0.25 \mathrm{~m}^{2}$ GWP-Il reactors}

The four Chlorella strains were cultivated outdoors in $1 \mathrm{~L}$ bubble tubes in either BG11 or F medium in a water

Table 1 Productivities of nine Chlorella strains grown in laboratory conditions in $300 \mathrm{~mL}$ tubes in their isolation medium

\begin{tabular}{|c|c|c|c|}
\hline \multirow[t]{2}{*}{ Strain } & \multicolumn{2}{|c|}{ Nutrient sufficient medium } & \multirow{2}{*}{$\frac{\text { Nitrogen starved medium }}{\text { Batch }\left(\mathrm{g} \mathrm{L}^{-1} \mathrm{~d}^{-1}\right)}$} \\
\hline & Batch $\left(g^{-1} d^{-1}\right)$ & Semi-continuous $\left(\mathrm{g} \mathrm{L}^{-1} \mathrm{~d}^{-1}\right)$ & \\
\hline F\&M-M49 & $0.64 \pm 0.05$ & $0.54 \pm 0.04$ & $0.23 \pm 0.02$ \\
\hline CCAP 211-11b & $0.59 \pm 0.02$ & $0.30 \pm 0.04$ & $0.32 \pm 0.04$ \\
\hline IAM C-212 & $0.71 \pm 0.05$ & $0.58 \pm 0.05$ & $0.18 \pm 0.04$ \\
\hline PROD1 & $0.73 \pm 0.01$ & $0.50 \pm 0.05$ & $0.43 \pm 0.03$ \\
\hline PAW2P2 & $0.71 \pm 0.02$ & $0.50 \pm 0.05$ & $0.46 \pm 0.03$ \\
\hline IRT2 & $0.62 \pm 0.00$ & $0.63 \pm 0.00$ & $0.29 \pm 0.02$ \\
\hline $\mathrm{BdR3}$ & $0.67 \pm 0.02$ & $0.51 \pm 0.02$ & $0.34 \pm 0.04$ \\
\hline MACH1 & $0.78 \pm 0.02$ & $0.58 \pm 0.03$ & $0.54 \pm 0.03$ \\
\hline $\mathrm{CH} 2$ & $0.75 \pm 0.02$ & $0.82 \pm 0.07$ & $0.50 \pm 0.04$ \\
\hline
\end{tabular}


Table 2 Biochemical composition of nine Chlorella strains grown in laboratory conditions in $300 \mathrm{~mL}$ tubes

\begin{tabular}{|c|c|c|c|c|c|c|c|c|}
\hline \multirow[t]{2}{*}{ Strain } & \multicolumn{4}{|c|}{ Nutrient sufficient medium } & \multicolumn{4}{|c|}{ Nitrogen starved medium } \\
\hline & Protein (\%) & Carbohydrate (\%) & Lipid (\%) & Ash (\%) & Protein (\%) & Carbohydrate (\%) & Lipid (\%) & Ash (\%) \\
\hline F\&M-M49 & $45.4 \pm 1.57$ & $24.2 \pm 0.60$ & $22.8 \pm 1.89$ & 4.8 & $28.2 \pm 2.74$ & $53.0 \pm 0.51$ & $15.4 \pm 0.60$ & 5.4 \\
\hline CCAP 211-11b & $44.1 \pm 1.18$ & $26.6 \pm 2.85$ & $22.0 \pm 2.13$ & 5.6 & $25.2 \pm 0.03$ & $24.3 \pm 3.34$ & $46.0 \pm 1.34$ & 5.2 \\
\hline IAM C-212 & $40.5 \pm 0.16$ & $26.8 \pm 0.23$ & $24.3 \pm 0.76$ & 6.3 & $25.9 \pm 3.76$ & $51.9 \pm 0.27$ & $17.1 \pm 0.67$ & 6.9 \\
\hline PROD1 & $39.9 \pm 0.84$ & $28.3 \pm 0.46$ & $28.1 \pm 0.20$ & 5.2 & $26.8 \pm 1.46$ & $21.5 \pm 3.87$ & $47.4 \pm 0.06$ & 5.9 \\
\hline PAW2P2 & $45.3 \pm 2.15$ & $27.1 \pm 0.61$ & $20.0 \pm 1.28$ & 5.8 & $22.1 \pm 0.04$ & $48.6 \pm 2.65$ & $22.5 \pm 0.39$ & 4.8 \\
\hline IRT2 & $38.0 \pm 1.84$ & $35.2 \pm 0.67$ & $20.5 \pm 0.03$ & 6.3 & $20.2 \pm 2.82$ & $47.1 \pm 0.93$ & $22.3 \pm 0.50$ & 8.5 \\
\hline BdR3 & $25.8 \pm 3.05$ & $35.6 \pm 3.08$ & $26.0 \pm 0.04$ & 8.3 & $24.6 \pm 0.20$ & $50.9 \pm 2.06$ & $17.8 \pm 2.03$ & 7.8 \\
\hline $\mathrm{MACH} 1$ & $39.4 \pm 3.37$ & $29.7 \pm 4.84$ & $25.6 \pm 0.24$ & 4.9 & $28.9 \pm 4.18$ & $47.7 \pm 2.22$ & $12.1 \pm 0.07$ & 8.2 \\
\hline $\mathrm{CH} 2$ & $39.3 \pm 1.63$ & $28.8 \pm 0.25$ & $23.1 \pm 0.03$ & 12.2 & $20.1 \pm 3.79$ & $20.3 \pm 0.56$ & $50.8 \pm 1.43$ & 12.0 \\
\hline
\end{tabular}

bath without temperature control. The temperature stayed above $35^{\circ} \mathrm{C}$ for an average of about 1.5 hours a day, but never exceeded $38^{\circ} \mathrm{C}$. The average global solar radiation during the experimental period was 27.4 $\mathrm{MJ} \mathrm{m} \mathrm{m}^{-2} \mathrm{~d}^{-1}$. Higher productivities were always achieved in $\mathrm{F}$ medium (Table 4) irrespective of the habitat of origin of the strains. In the case of PROD1, productivity in the seawater-based medium almost tripled with respect to the freshwaterbased medium. Strain $\mathrm{CH} 2$ in the seawater-based medium achieved $1 \mathrm{~g} \mathrm{~L}^{-1} \mathrm{~d}^{-1}$ (Table 4).

Given the results of the previous outdoor experiment in tubes, the four selected strains were grown in northsouth oriented $0.25 \mathrm{~m}^{2}$ vertical GWP-II reactors without temperature control. When the culture temperature stayed above $40^{\circ} \mathrm{C}$ for $3-4$ hours every day, none of the cultures survived more than 3 days neither in BG11 nor in F medium (data not shown). Besides, the protein content was always low (21 to 26\%). Carbohydrates in F\&M-M49 (47\%) and IAM C-212 (44\%) or lipids in CH2 (34\%) and PROD1 (32\%) accumulated well beyond the typical content.
Outdoor cultivation of four selected Chlorella strains in $0.25 \mathrm{~m}^{2}$ GWP-II reactors in nutrient sufficient and nitrogen deprived media

The four selected strains were grown in north-south oriented $0.25 \mathrm{~m}^{2}$ vertical GWP-II reactors to compare performances in nitrogen sufficient and nitrogen starved seawater-based media. Given the negative results of the previous outdoor trial without temperature control, for this trial the control system was set up so as to allow the culture temperature to increase during daylight but never surpass $40^{\circ} \mathrm{C}$. The nutrient sufficient cultures grew well for the 5 days of the trial (Figure 1). $\mathrm{CH} 2$ was by far the most productive $\left(0.6 \mathrm{~g} \mathrm{~L}^{-1} \mathrm{~d}^{-1}\right)$ (Table 5$)$. Under nitrogen starvation F\&M-M49 ceased to grow after 3 days and IAM C-212 and $\mathrm{CH} 2$ after 4 days (Figure 1). Only PROD1 grew, albeit slowly, for the whole experimental period. Nitrogen starvation strongly reduced productivity in all the strains: of about 50\% in F\&M-M49, IAM C-212 and $\mathrm{CH} 2$, and of $30 \%$ in PROD1 (Table 5). In nutrient sufficient conditions biomass composition was similar in all

Table 3 Productivities of nine Chlorella strains at high temperature and in different culture media in laboratory conditions in $\mathbf{4 0} \mathbf{~ m L}$ tubes

\begin{tabular}{|c|c|c|c|c|}
\hline \multirow[t]{2}{*}{ Strain } & \multicolumn{2}{|c|}{ High temperature trial } & \multicolumn{2}{|c|}{ Culture medium trial } \\
\hline & $\begin{array}{l}\text { Control } 8 \mathrm{~h}: 16 \mathrm{~h}^{\mathrm{a}} \text { at } \\
25^{\circ} \mathrm{C}^{\mathrm{c}}\left(\mathrm{g} \mathrm{L}^{-1} \mathrm{~d}^{-1}\right)\end{array}$ & $\begin{array}{c}\text { High temperature } 8 \mathrm{~h} \text { at } 40^{\circ} \mathrm{C} ; \\
16 \mathrm{~h} \text { at } 25^{\circ} \mathrm{C}^{\mathrm{C}}\left(\mathrm{g} \mathrm{L}^{-1} \mathrm{~d}^{-1}\right)\end{array}$ & $\begin{array}{l}\text { Freshwater medium } 24 \mathrm{~h}^{\mathrm{b}} ; \\
25^{\circ} \mathrm{C} \text { constant }\left(\mathrm{g} \mathrm{L}^{-1} \mathrm{~d}^{-1}\right)\end{array}$ & $\begin{array}{l}\text { Seawater medium } 24 \mathrm{~h}^{\mathrm{b}} ; \\
25^{\circ} \mathrm{C} \text { constant }\left(\mathrm{g} \mathrm{L}^{-1} \mathrm{~d}^{-1}\right)\end{array}$ \\
\hline F\&M-M49 & $0.42 \pm 0.02$ & $0.57 \pm 0.01$ & $0.37 \pm 0.02$ & $0.33 \pm 0.00$ \\
\hline CCAP211-11b & $0.34 \pm 0.02$ & NG & $0.56 \pm 0.01$ & $0.42 \pm 0.01$ \\
\hline IAM C-212 & $0.66 \pm 0.02$ & $0.80 \pm 0.05$ & $0.40 \pm 0.01$ & $0.43 \pm 0.01$ \\
\hline PROD1 & $0.64 \pm 0.01$ & NG & $0.53 \pm 0.02$ & $0.73 \pm 0.01$ \\
\hline PAW2P2 & $0.30 \pm 0.01$ & NG & $0.42 \pm 0.01$ & $0.38 \pm 0.02$ \\
\hline IRT2 & $0.59 \pm 0.02$ & $0.41 \pm 0.02$ & $0.48 \pm 0.01$ & $0.66 \pm 0.01$ \\
\hline $\mathrm{BdR3}$ & $0.34 \pm 0.01$ & $0.16 \pm 0.02$ & $0.58 \pm 0.00$ & $0.60 \pm 0.02$ \\
\hline $\mathrm{MACH} 1$ & $0.27 \pm 0.02$ & $0.69 \pm 0.02$ & $0.30 \pm 0.01$ & $0.24 \pm 0.00$ \\
\hline $\mathrm{CH} 2$ & $0.45 \pm 0.01$ & $1.00 \pm 0.04$ & $0.44 \pm 0.01$ & $0.58 \pm 0.01$ \\
\hline
\end{tabular}

${ }^{\mathrm{a}} 8 \mathrm{~h}: 16 \mathrm{~h}$, light:dark cycle; ${ }^{\mathrm{b}} 24 \mathrm{~h}$, continuous illumination; ${ }^{c}$ culture performed in each strain isolation medium; $\mathrm{NG}$, no growth. 
Table 4 Productivity of four selected Chlorella strains cultivated outdoors in $1 \mathrm{~L}$ tubes without temperature control

\begin{tabular}{|c|c|c|}
\hline Strain & BG11 $\left(g^{-1} d^{-1}\right)$ & $F\left(g L^{-1} d^{-1}\right)$ \\
\hline F\&M-M49 & $0.36 \pm 0.03$ & $0.69 \pm 0.01$ \\
\hline IAM C-212 & $0.33 \pm 0.01$ & $0.48 \pm 0.01$ \\
\hline PROD1 & $0.23 \pm 0.08$ & $0.63 \pm 0.02$ \\
\hline $\mathrm{CH} 2$ & $0.87 \pm 0.23$ & $1.02 \pm 0.01$ \\
\hline
\end{tabular}

the strains, with a protein content of about $40 \%$ and an about half content of carbohydrate (20 to 25\%) and lipid (20 to 26\%), thus confirming previous laboratory and outdoor results. Nitrogen starvation strongly reduced protein in all the strains, and triggered a gradual accumulation of the typical storage product, which reached the maximum content after 5 days. As observed in the laboratory, F\& M-M49 and IAM C-212 accumulated carbohydrate (up to about $50 \%$ ), while PROD1 and $\mathrm{CH} 2$ accumulated lipids (up to about 40\%) (Table 6). The high lipid productivity of $\mathrm{CH} 2\left(0.12 \mathrm{~g} \mathrm{~L}^{-1} \mathrm{~d}^{-1}\right)$ and, particularly, the high carbohydrate productivity of F\&M-M49 $\left(0.19 \mathrm{~g} \mathrm{~L}^{-1} \mathrm{~d}^{-1}\right)$ under nitrogen starvation were noteworthy (Table 5). However, lipid productivity in $\mathrm{CH} 2$ was higher in nutrient sufficiency.

During this experiment, carried out in September, with an average solar radiation on the horizontal of 17.0 MJ $\mathrm{m}^{-2} \mathrm{~d}^{-1}$, the $0.25 \mathrm{~m}^{2}$ vertical panel intercepted on average $4.26 \mathrm{MJ} \mathrm{d}^{-1}$. Under nutrient sufficiency strain $\mathrm{CH} 2$ produced $6 \mathrm{~g}$ biomass $\mathrm{d}^{-1}, 2.4 \mathrm{~g}_{\text {protein }} \mathrm{d}^{-1}$ and $1.6 \mathrm{~g}$ lipid $\mathrm{d}^{-1}$. Under nitrogen starvation lipid production decreased to $1.2 \mathrm{~g} \mathrm{~d}^{-1}$. The photosynthetic efficiency (PE) achieved by strain $\mathrm{CH} 2$ was thus: $1.4 \mathrm{~g}$ biomass, $0.55 \mathrm{~g}$ protein and $0.38 \mathrm{~g}$ lipid per $\mathrm{MJ}$ received, under nutrient sufficiency, and $0.28 \mathrm{~g}$ lipid per MJ received under nitrogen starvation.

\section{Biomass and lipid productivity potential of Chlorella strain $\mathrm{CH} 2$}

From the biomass, lipid and protein productivity data attained with Chlorella strain $\mathrm{CH} 2$ in the isolated vertical GWP in September, we extrapolated the areal productivity of a scaled-up (1 ha) plant of panels. The rationale for the calculation was the following: in the 1 ha plant the GWP reactors are placed in south-facing parallel rows at the minimum distance (D) between rows that avoids shading of direct radiation among the panels. This distance varies monthly and allows the scaled-up panels to receive the same amount of direct sunlight as an isolated single row of panels. Diffuse light received by the scaled-up panels will be, on the contrary, reduced by a significant fraction compared to the single row because they are closely spaced and see only a portion of the sky.
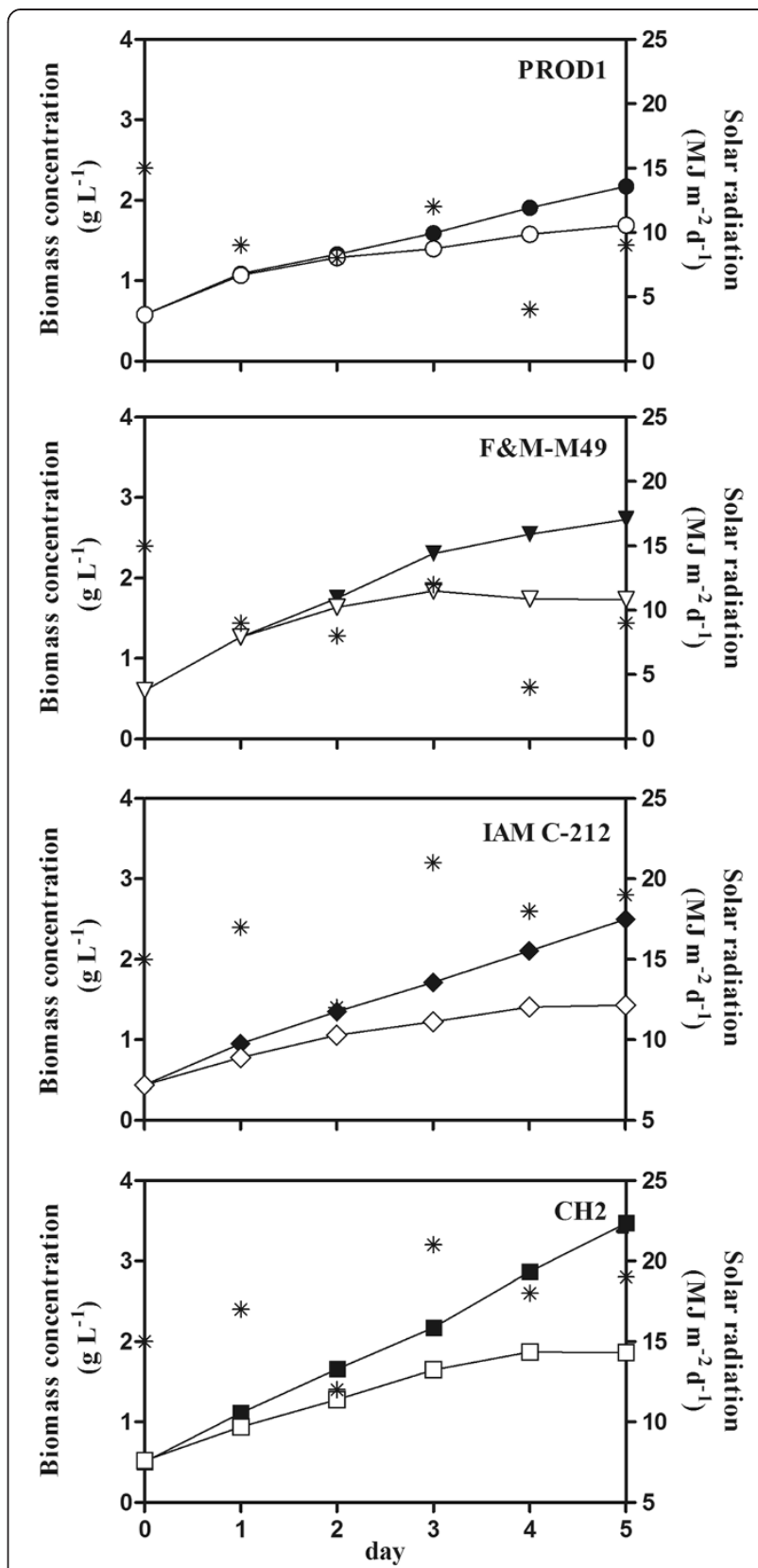

Figure 1 Growth of four selected Chlorella strains cultivated outdoors in $0.25 \mathrm{~m}^{2}$ GWP-II under nitrogen starvation and nutrient sufficiency. Growth, expressed as biomass concentration, of four Chlorella strains in $0.25 \mathrm{~m}^{2}$ GWP-II reactors in F medium. Cultures under nutrient sufficiency are indicated by filled symbols, starved cultures by empty symbols. Daily global solar radiation is indicated by an asterisk. Temperature controlled at $40^{\circ} \mathrm{C}$.

The diffuse and ground-reflected radiation on the panels was calculated for each month from April to September and added to the intercepted direct radiation to have the total radiation impinging on the panels. The monthly total radiation on the scaled-up panels and the PE values obtained in our experiments by strain $\mathrm{CH} 2$ (see previous 
Table 5 Productivity of four selected Chlorella strains cultivated outdoors in $0.25 \mathbf{~ m}^{2}$ GWP-II under nitrogen starvation and nutrient sufficiency

\begin{tabular}{|c|c|c|c|c|}
\hline \multirow[t]{2}{*}{ Strain } & \multicolumn{2}{|c|}{ Nutrient sufficient cultures } & \multicolumn{2}{|c|}{ Starved cultures } \\
\hline & $\overline{\text { Biomass }\left(\mathrm{g} \mathrm{L}^{-1} \mathrm{~d}^{-1}\right)}$ & Storage product $\left(\mathrm{g} \mathrm{L}^{-1} \mathrm{~d}^{-1}\right)$ & Biomass ( $\mathrm{g} \mathrm{L}^{-1} \mathrm{~d}^{-1}$ ) & Storage product $\left(\mathrm{g} \mathrm{L}^{-1} \mathrm{~d}^{-1}\right)$ \\
\hline F\&M-M49 & 0.43 & 0.08 carbohydrate & 0.23 & 0.19 carbohydrate \\
\hline IAM C-212 & 0.41 & 0.14 carbohydrate & 0.20 & 0.12 carbohydrate \\
\hline PROD1 & 0.32 & 0.06 lipid & 0.22 & 0.10 lipid \\
\hline $\mathrm{CH}_{2}$ & 0.60 & 0.16 lipid & 0.27 & 0.12 lipid \\
\hline
\end{tabular}

paragraph) were finally used to calculate the potential productivity (in terms of biomass, protein and lipid) of the 1 ha plant (Table 7).

\section{Discussion}

This study was aimed to find a strategy to reduce the costs and environmental impacts of Chlorella biomass production under autotrophic conditions in large-scale plants. In particular, the following changes with respect to the standard industrial cultivation procedures were investigated: the use of a seawater-based medium, none or limited temperature control, nitrogen deprivation when carbohydrates or lipids are the target products. To this end, nine Chlorella strains were first screened in the laboratory to test their performance under different culture conditions. Then the four best strains were evaluated outdoors.

Temperature control (cooling) is one of the main operative costs of algal biomass production in closed reactors $[45,51]$. To reduce costs related to thermoregulation, the use of thermotolerant strains has been proposed [52]. In this work, all the four selected Chlorella strains showed good growth at or below $38^{\circ} \mathrm{C}$, when cultivated outdoors in bubble tubes, confirming the results previously obtained in the laboratory. The trials performed in GWP-II reactors showed that the four Chlorella strains could survive for a few days when the temperature exceeded $40^{\circ} \mathrm{C}$ for $3-4$ hours a day. Few works deal with Chlorella cultivation at temperatures higher than $40^{\circ} \mathrm{C}$, particularly outdoors. de-Bashan et al. showed that immobilized $C$. sorokiniana cells were able to grow when exposed for 5 hours daily at temperatures of $40^{\circ} \mathrm{C}$ and high irradiance $\left(2,500 \mu \mathrm{mol}\right.$ photons $\left.\mathrm{m}^{-2} \mathrm{~s}^{-1}\right)$ in a $1 \mathrm{~L}$ fermenter [53]. Morita et al. cultivated C. sorokiniana indoors in a conical helical tubular photobioreactor covering an area of $0.5 \mathrm{~m}^{2}$, in which the strain was kept at $40^{\circ} \mathrm{C}$ and under a light intensity of $980 \mu \mathrm{mol}$ photons $\mathrm{m}^{-2} \mathrm{~s}^{-1}$ (12 h:12 h light:dark cycle), obtaining a biomass productivity of $1.23 \mathrm{~g} \mathrm{~L}^{-1} \mathrm{~d}^{-1}$ $\left(34.4 \mathrm{~g} \mathrm{~m}^{-2}\right.$ of installation area $\left.\mathrm{d}^{-1}\right)$ [54]. Feng et al. studied the feasibility of $C$. zofingiensis outdoor cultivation in $60 \mathrm{~L}, 17 \mathrm{~cm}$ thick, flat plate photobioreactors in spring, without temperature control, obtaining maximum biomass productivities of $0.06 \mathrm{~g} \mathrm{~L}^{-1} \mathrm{~d}^{-1}$ (about $10 \mathrm{~g} \mathrm{~m}^{-2}$ of directly illuminated reactor surface $\mathrm{d}^{-1}$ ), although, in this study, the culture temperature never surpassed $40^{\circ} \mathrm{C}$ [31]. Béchet et al. cultivated C. sorokiniana outdoors without temperature control (maximum temperature of the culture was $41^{\circ} \mathrm{C}$ ) in a $51 \mathrm{~L}$ cylinder photobioreactor, with a productivity of $0.21 \mathrm{~g} \mathrm{~L}^{-1} \mathrm{~d}^{-1}\left(10 \mathrm{~g} \mathrm{~m}^{-2}\right.$ of directly illuminated surface $\mathrm{d}^{-1}$ ) [50]. The productivities measured by us in the GWP-II are comparable or higher than those attained in these studies carried out outdoors without temperature control. The biomass of cultures grown at inhibiting temperatures (maxima from 47 to $50^{\circ} \mathrm{C}$ ) showed an increased content of storage product and a marked decrease of protein in all the strains. A similar change in biomass composition caused by high temperatures was shown by Han et al. in C. pyrenoidosa cultivated outdoors in a $50 \mathrm{~L}$ open tank; at daytime temperatures varying from 30 to $36^{\circ} \mathrm{C}$, lipid content increased by about $40 \%$ compared to the culture kept below $30^{\circ} \mathrm{C}$ [55].

An important limitation of large-scale algae cultures for protein or energy production is competition for freshwater with traditional crops. To avoid or reduce the impact on freshwater resources, algae must be cultivated in brackish water or seawater $[27,44]$. No data are available, to our knowledge, on cultivation at high salinities $\left(\geq 30 \mathrm{~g} \mathrm{~L}^{-1}\right)$ of Chlorella strains isolated from freshwater.

Table 6 Biomass biochemical composition of four selected Chlorella strains cultivated outdoors in $0.25 \mathrm{~m}^{2}$ GWP-II under nitrogen starvation and nutrient sufficiency

\begin{tabular}{|c|c|c|c|c|c|c|c|c|}
\hline \multirow[t]{2}{*}{ Strain } & \multicolumn{4}{|c|}{ Nutrient sufficient cultures } & \multicolumn{4}{|c|}{ Nitrogen starved cultures } \\
\hline & Protein (\%) & Carbohydrate (\%) & Lipid (\%) & Ash (\%) & Protein (\%) & Carbohydrate (\%) & Lipid (\%) & Ash (\%) \\
\hline F\&M-M49 & $40.5 \pm 4.38$ & $20.3 \pm 2.04$ & $19.7 \pm 0.22$ & 17.4 & $17.5 \pm 3.88$ & $46.6 \pm 0.66$ & $16.1 \pm 0.56$ & 16.6 \\
\hline IAM C-212 & $39.8 \pm 4.38$ & $24.6 \pm 0.57$ & $24.2 \pm 0.02$ & 11.5 & $16.6 \pm 3.28$ & $51.0 \pm 0.68$ & $18.4 \pm 0.05$ & 13.3 \\
\hline PROD1 & $41.3 \pm 2.82$ & $25.4 \pm 0.61$ & $20.2 \pm 0.16$ & 13.0 & $25.7 \pm 2.78$ & $22.2 \pm 1.45$ & $39.2 \pm 0.03$ & 13.2 \\
\hline $\mathrm{CH}_{2}$ & $38.9 \pm 3.67$ & $20.8 \pm 1.30$ & $26.0 \pm 0.02$ & 15.1 & $26.1 \pm 3.32$ & $17.2 \pm 0.59$ & $40.0 \pm 0.15$ & 13.8 \\
\hline
\end{tabular}


Table 7 Biomass, lipid and protein potential productivity of Chlorella strain CH2 in a 1 ha GWP-II plant located in central Italy

\begin{tabular}{|c|c|c|c|c|c|c|}
\hline Month & $\begin{array}{l}\text { Average total solar } \\
\text { radiation on the horizontal } \\
\left(\mathrm{GJ} \mathrm{ha} \mathrm{month}^{-1}\right)^{\mathrm{a}}\end{array}$ & $\begin{array}{c}\text { Minimum } \\
\text { distance } D(m)\end{array}$ & $\begin{array}{c}\text { Total radiation } \\
\text { on panels } \\
\left(\mathrm{GJ} \mathrm{ha}^{-1} \text { month }^{-1}\right)\end{array}$ & $\begin{array}{c}\text { Biomass } \\
\text { productivity } \\
\left(\mathrm{t} \mathrm{ha}^{-1} \text { month }^{-1}\right)\end{array}$ & $\begin{array}{l}\text { Protein productivity } \\
\left(\mathrm{t} \mathrm{ha} \mathrm{month}^{-1}\right)\end{array}$ & $\begin{array}{l}\text { Lipid productivity } \\
\begin{array}{c}\text { (t ha }^{-1} \text { month }^{-1} \text { ) } \\
+\mathrm{N} /-\mathrm{N}\end{array}\end{array}$ \\
\hline April & 5,280 & 0.40 & 3,590 & 5.06 & 1.97 & $1.32 / 1.00$ \\
\hline May & 6,975 & 0.26 & 4,883 & 6.88 & 2.68 & $1.79 / 1.37$ \\
\hline June & 7,410 & 0.20 & 5,261 & 7.42 & 2.89 & $1.93 / 1.47$ \\
\hline July & 8,060 & 0.20 & 5,884 & 8.30 & 3.24 & $2.16 / 1.65$ \\
\hline August & 6,540 & 0.25 & 5,569 & 7.85 & 3.06 & $2.04 / 1.56$ \\
\hline September & 4,950 & 0.40 & 3,960 & 5.58 & 2.18 & $1.45 / 1.11$ \\
\hline
\end{tabular}

${ }^{a}$ Data retrieved from the Photovoltaic Geographical Information System (PVGIS) (http://re.jrc.ec.europa.eu/pvgis) for Florence latitude; D, minimum distance that avoids shading; $+\mathrm{N}$, under nutrient sufficiency; $-\mathrm{N}$, nitrogen starvation.

In this work, all the strains were tested for their ability to grow in a seawater-based medium. Surprisingly, outdoors without temperature control, the four selected strains performed better in the seawater-based medium independently of their habitat of origin, and thus this medium was adopted for the starvation trials in the GWP-II reactors. It is worth noting that the salinity of the growth medium did not influence biomass composition neither in nutrient sufficiency nor in nitrogen starved conditions.

In several algae, nutritional stresses, for example, deprivation of nitrogen or phosphorus, limit cell growth, while increasing lipid $[43,56-58]$ or carbohydrate $[35,59,60]$ content. For this reason, nutrient deficiency has been regarded as one of the most efficient approaches to increase storage product content for biofuels [43,61]. In our trials outdoors, nitrogen starvation led to a significant decrease of biomass productivity compared to nutrient sufficient conditions (on average 0.23 and $0.44 \mathrm{~g} \mathrm{~L}^{-1} \mathrm{~d}^{-1}$, respectively), and increased accumulation of the storage product for all the strains. Under nitrogen starvation strain F\&M-M49 was the best performer in terms of carbohydrate productivity $\left(0.19 \mathrm{~g} \mathrm{~L}^{-1} \mathrm{~d}^{-1}\right)$, while $\mathrm{CH} 2$ was the best lipid producer $\left(0.12 \mathrm{~g} \mathrm{~L}^{-1} \mathrm{~d}^{-1}\right)$. It is also noteworthy that in the latter strain lipid productivity under nutrient sufficiency was higher than following nitrogen starvation. However, neutral lipids, suitable for biodiesel, are only or mainly accumulated under nutrient stress [56,61-63]. In all the strains, protein content decreased under nitrogen starvation; however, strains $\mathrm{CH} 2$ and PROD1 maintained a good protein content (about 26\%) at the end of the starvation period. Given the high biomass, protein and lipid productivity in a seawater-based medium, and higher thermotolerance, strain $\mathrm{CH} 2$ shows high potential for food and biofuel production in hot arid climates.

Although a vast amount of literature on Chlorella cultivation for biofuels is now available [60,64-67], only a few works have been carried out outdoors under autotrophic conditions. Zhou et al. cultivated Chlorella sp. outdoors in a $70 \mathrm{~L}, 22 \mathrm{~cm}$ wide, $185 \mathrm{~cm}$ high vertical photobioreactor, obtaining a $47 \%$ increase in lipid content and a lipid productivity of about $15 \mathrm{mg} \mathrm{L}^{-1} \mathrm{~d}^{-1}$ under nitrogen starvation [68]. Feng et al. cultivated C. zofingiensis in a $60 \mathrm{~L}$ flat plate photobioreactor under nitrogen starvation attaining a maximum lipid productivity of $22.3 \mathrm{mg} \mathrm{L}^{-1} \mathrm{~d}^{-1}$ (about $4 \mathrm{~g} \mathrm{~m}^{-2}$ of directly illuminated reactor surface $\mathrm{d}^{-1}$ ) [31]. Münkel et al. cultivated C. vulgaris in a $30 \mathrm{~L}, 3 \mathrm{~cm}$ thick Flat Panel Airlift reactor under nitrogen and phosphorus starvation (14 days) [32]. The best average biomass and fatty acid productivities (about 0.67 and $0.39 \mathrm{~g} \mathrm{~L}^{-1} \mathrm{~d}^{-1}$ corresponding to 20.1 and $11.7 \mathrm{~g} \mathrm{~m}^{-2}$ of directly illuminated reactor surface $\mathrm{d}^{-1}$, respectively) were obtained at the highest cell concentration $\left(4 \mathrm{~g} \mathrm{~L}^{-1}\right)$. This latter productivity is among the highest ever reported. The productivity obtained by us with Chlorella strain $\mathrm{CH} 2$ grown in a seawater-based medium, both in terms of volumetric and areal productivities $\left(0.12 \mathrm{~g} \mathrm{~L}^{-1} \mathrm{~d}^{-1}\right.$ corresponding to $4.9 \mathrm{~g} \mathrm{~m}^{-2}$ of directly illuminated reactor surface $\mathrm{d}^{-1}$ ), compares well with the literature values. Few works are available on starch accumulation in Chlorella cultivated outdoors. Brányiková et al. cultivated Chlorella sp. in a thin-layer cascade pond to maximize starch content through sulfur limitation, attaining values of about $50 \%$ [35]. According to these authors, sulfur limitation increases starch to a level that would be viable for bioethanol production. Our strains F\&M-M49 and IAM C-212 were able to accumulate comparable amounts of carbohydrates under nitrogen starvation.

To produce algal biomass at low cost, compatible with biofuel or food production, it is necessary to significantly reduce capital and operational costs of the culture system. In this work, the strategies used to reduce the costs of Chlorella production were the use of a low-cost photobioreactor, the GWP-II $[44,45,51,69]$, and the reduction of cooling needs. In fact, all the outdoor trials were carried out with cooling activated only above $40^{\circ} \mathrm{C}$. Bassi and Tredici (unpublished) have calculated that, in a plant made of east-west oriented vertical GWP-II, 
located in central Italy, if the culture temperature is maintained at $27^{\circ} \mathrm{C}$, the energy consumption due to cooling is about $15 \%$ of the total energy used to operate the plant. Maintaining the culture temperature at $40^{\circ} \mathrm{C}$ reduces the cooling contribution to $1 \%$ of the total operational energy costs.

Although most of the scientific community and industry consider open ponds as more economically convenient for algae cultivation compared to photobior eactors $[46,70,71]$, it is undeniable that ponds suffer several limitations that make them unsuitable for largescale production of algae unless the cultivated organisms have very specific requirements (for example, high $\mathrm{pH}$ or high salinity). According to Norsker et al. production of algae in flat panels and tubular photobioreactors may become cheaper than in raceway ponds within 10 years [26].

Our work shows that significant savings can indeed be attained with thermotolerant algae and that the potential of selected Chlorella strains in flat reactors is very high when compared with the typical yields of traditional crops.

The potential in productivity terms of a large-scale GWP-II plant located in central Italy with Chlorella $\mathrm{CH} 2$ is of 41 tonnes of biomass, 16 tonnes of protein and 11 tonnes of lipid under nutrient sufficiency, and of 8 tonnes of lipid under nitrogen starvation. In a more favourable location (for example, North Africa) allowing year-round cultivation, the potential productivity would surpass 80, 32 and 22 tonnes per year for biomass, protein and lipid, respectively. Under nitrogen deficiency, lipid productivity decreases, but mainly neutral lipids, more suitable for biofuels, are accumulated [62] and the lipid content of the biomass rises to $40 \%$, which greatly favors extraction. Besides, another important advantage is obtained as the amount of nutrients (for example, nitrogen) supplied to the culture can be significantly reduced.

Note that the above figures show the potential in terms of productivity, but do not provide any evaluation in terms of plant cost or energy efficiency. In reality, placing the panel rows so close to each other has benefits as it maximizes solar radiation interception, but also drawbacks in terms of high capital and operational costs. Besides, it is unlikely that a plant will adopt movable panels or erect a variable number of rows during the cultivation season. A possible solution to capture a high fraction of the solar radiation impinging on the horizontal with a more economic and simple arrangement would be to adopt a fixed minimum distance for the whole period and tilt the reactors (for example, at $45^{\circ}$ with respect to the horizontal). This will allow a higher amount of solar energy to be harvested with a reduced number of panels. However, in this case a reduction of the PE is likely, since the beneficial effects of light dilution are lost.
Only detailed economical and life-cycle analyses will provide the solution to optimize panel orientation and placement for maximum economic return and reduced environmental impact.

\section{Conclusions}

This work aimed to develop strategies for enhancing the environmental and economic sustainability of microalgal biomass production for food, biofuels and other feedstocks. Four selected Chlorella strains were cultivated outdoors in closed reactors (the GWP) with limited temperature control, so allowing for a significant saving in energy expenditure for cooling. Besides, all the strains performed very well in a seawater-based culture medium, a crucial feature if we aim at an environmentally sustainable production process. These features make feasible the cultivation of Chlorella in regions of high year-round solar irradiation, where temperature is generally high and freshwater availability limited $[72,46]$, using lands and waters unsuitable for conventional agriculture. In these climates the potential productivity of Chlorella surpasses 80 tonnes of biomass, 32 tonnes of proteins and 22 tonnes of lipids per hectare per year. Extraction of the target product from both the nutrient sufficient and nitrogen starved biomasses (for example, protein or lipid), would leave important amounts of residues that could find application as biomaterials or energy feedstocks.

\section{Methods}

The nine Chlorella strains screened in the laboratory for their growth capacity in different culture conditions are listed in Table 8. The laboratory screening trials are reported in Table 9. The outdoor trials (Table 10) were performed on four selected strains.

\section{Laboratory culture conditions}

Culture media were BG11 (freshwater-based medium) [73] and F (seawater-based medium) [74]. BG11 was sterilized in an autoclave. F medium was prepared with artificial seawater (Adriatic Sea Aquarium \& Equipment, Rimini, Italy) at $30 \mathrm{~g} \mathrm{~L}^{-1}$ salinity, autoclaved, allowed to cool and then added with sterile nutrient solutions. For BG11 medium initial $\mathrm{NaNO}_{3}$ and $\mathrm{K}_{2} \mathrm{HPO}_{4}$ concentrations of 1.5 and $0.14 \mathrm{~g} \mathrm{~L}^{-1}$, respectively, were used, whereas for $\mathrm{F}$ medium the initial concentrations were of 1.5 and $0.11 \mathrm{~g} \mathrm{~L}^{-1}$, respectively. When necessary nutrients were added during cultivation according to productivity to avoid limitation, considering $\mathrm{N}$ as $10 \%$ and $\mathrm{P}$ as $1 \%$ of the biomass. For all the laboratory trials, cultures were bubbled with an air $/ \mathrm{CO}_{2}$ mixture $(98 / 2, \mathrm{v} / \mathrm{v})$ to provide mixing and maintain $\mathrm{pH}$ in the optimal range (7.5 to $8)$, as well as to provide carbon. All the tubes were immersed in a thermoregulated water bath to maintain a constant temperature. For all the trials the initial cell 
Table 8 Chlorella strains used for the experiments

\begin{tabular}{lrc}
\hline Strain & Origin & Isolation medium \\
\hline $\begin{array}{l}\text { Chlorella sp. F\&M-M49 } \\
\text { Chlorella vulgaris CCAP211-11b } \\
\text { Chlorella sorokiniana IAM C-212 }\end{array}$ & Fotosintetica \& Microbiologica Culture Collection (Florence, Italy) & BG11 \\
Chlorella sp. PROD1 & Culture Collection of Algae and Protozoa (Argyll, UK) & BG11 \\
Chlorella sp. PAW2P2 & IslES) (Tsukuba, Japan) & BG11 \\
Chlorella sp. IRT2 & Isolated from a pig manure storage lagoon (Lombardia, Italy) & BG11 \\
Chlorella sp. BdR3 & Isolated from urban drainage water (Tabriz, Iran) & BG11 \\
Chlorella sp. MACH1 & Isolated from thermal mud (Bagno di Romagna, Italy) & BG11 \\
Chlorella sp. CH2 & Isolated from a rainwater puddle (Machala, Ecuador) & BG11 \\
\hline
\end{tabular}

concentration was $0.2 \mathrm{~g} \mathrm{~L}^{-1}$. An experimental plan of the trials is shown in Table 9. The screening trials 1, 2 and 3 on the nine Chlorella strains were carried out in duplicate in 7-day long experiments, using $300 \mathrm{~mL}$, $40 \mathrm{~mm}$ in diameter glass tubes, under a continuous one-side illumination of $400 \mu \mathrm{mol}$ photons $\mathrm{m}^{-2} \mathrm{~s}^{-1}$ provided by fluorescent daylight lamps. A constant temperature of $25^{\circ} \mathrm{C}$ was maintained. Each strain was tested in its isolation medium (Table 8 ). The first trial was performed in batch regime while the second in semi-continuous regime $(30 \%$ of the culture volume was harvested daily and replaced with fresh medium). The third laboratory trial was carried out in nitrogen starvation in batch conditions; the trial was started by inoculating the alga in the growth medium deprived of nitrogen. Growth of starved cultures was compared to that of a culture in nutrient replete medium (control). The capacity of the strains to grow at high temperature (trial 4) was tested in duplicate in 4-day long experiments, in batch regime using $40 \mathrm{~mL}, 20 \mathrm{~mm}$ in diameter glass tubes. A light:dark cycle ( $8 \mathrm{~h}: 16 \mathrm{~h})$ matching with the temperature cycle, that is, $40^{\circ} \mathrm{C}$ during the 8 light hours and $25^{\circ} \mathrm{C}$ during the 16 dark hours, was applied. The cultures were illuminated from two sides with $200 \mu \mathrm{mol}$ photons $\mathrm{m}^{-2} \mathrm{~s}^{-1}$ provided by metal halide lamps. The strains were tested in their isolation medium. Control cultures were maintained at $25^{\circ} \mathrm{C}$ applying the same light:dark cycle. A 7-day trial (Table 9, trial 5) to test the effect of culture medium was performed in $40 \mathrm{~mL}$ bubble tubes, in batch regime, under continuous two-side illumination and at a constant temperature of $25^{\circ} \mathrm{C}$. For this trial the inocula were grown in the respective isolation medium, centrifuged, washed with deionized water and centrifuged again, then the biomass was re-suspended in the experimental culture medium.

\section{Outdoor culture conditions}

The outdoor trials on the four selected strains were carried out at the experimental area of Fotosintetica \& Microbiologica S.r.l. located in Sesto Fiorentino (Florence, Italy) in the summer (July to September). An experimental plan of the trials is shown in Table 10. Culture media were BG11 and F, as in the laboratory screening. BG11 for outdoor cultures was prepared from tap water which was filtered through 10 and $1 \mu \mathrm{m}$ polypropylene filters (Domnick Hunter, St Neots, UK) and then added with sterile nutrient solutions. F medium was prepared with tap water as described above and treated as for BG11 preparation. In both media nutrient concentration was adjusted as for laboratory trials. For all the trials the

Table 9 Plan of the experiments for screening the nine Chlorella strains in the laboratory

\begin{tabular}{|c|c|c|c|c|c|c|}
\hline Trial & $\begin{array}{l}\text { Duration } \\
\text { (days) }\end{array}$ & Culture system & $\begin{array}{l}\text { Culture } \\
\text { regime }\end{array}$ & $\begin{array}{l}\text { Light regime } \\
\text { and intensity }\end{array}$ & Culture medium & Temperature \\
\hline 1. Batch growth & 7 & $\begin{array}{l}300 \mathrm{~mL} \text { bubble } \\
\text { tubes }\end{array}$ & Batch & $\begin{array}{c}\text { Continuous light } \\
\left(400 \mu \mathrm{mol} \text { photons } \mathrm{m}^{-2} \mathrm{~s}^{-1}\right)\end{array}$ & Isolation ${ }^{a}$ medium & $25^{\circ} \mathrm{C}$ \\
\hline $\begin{array}{l}\text { 2. Semi-continuous } \\
\text { growth }\end{array}$ & 7 & $\begin{array}{l}300 \mathrm{~mL} \text { bubble } \\
\text { tubes }\end{array}$ & $30 \%$ daily dilution & $\begin{array}{c}\text { Continuous light }(400 \mu \mathrm{mol} \\
\left.\text { photons } \mathrm{m}^{-2} \mathrm{~s}^{-1}\right)\end{array}$ & Isolation ${ }^{a}$ medium & $25^{\circ} \mathrm{C}$ \\
\hline 3. Starvation & 7 & $\begin{array}{c}300 \text { mL bubble } \\
\text { tubes }\end{array}$ & Batch & $\begin{array}{l}\text { Continuous light }(400 \mu \mathrm{mol} \\
\left.\text { photons } \mathrm{m}^{-2} \mathrm{~s}^{-1}\right)\end{array}$ & Isolation ${ }^{a}$ medium & $25^{\circ} \mathrm{C}$ \\
\hline 4. High temperature & 4 & $\begin{array}{l}40 \mathrm{~mL} \text { bubble } \\
\text { tubes }\end{array}$ & Batch & $\begin{array}{l}\text { Light:dark cycle }(8 \mathrm{~h}: 16 \mathrm{~h}) \\
\left(200 \mu \mathrm{mol} \text { photons } \mathrm{m}^{-2} \mathrm{~s}^{-1}\right)\end{array}$ & Isolation ${ }^{\mathrm{a}}$ medium & $\begin{array}{l}40^{\circ} \mathrm{C} \text { for } 8 \mathrm{~h}-25^{\circ} \mathrm{C} \text { for } 16 \mathrm{~h} \text {; } \\
\text { control cultures } 24 \mathrm{~h} \text { at } 25^{\circ} \mathrm{C}\end{array}$ \\
\hline 5. Culture medium & 7 & $\begin{array}{l}40 \mathrm{~mL} \text { bubble } \\
\text { tubes }\end{array}$ & Batch & $\begin{array}{l}\text { Continuous light }(200 \mu \mathrm{mol} \\
\left.\text { photons } \mathrm{m}^{-2} \mathrm{~s}^{-1}\right)\end{array}$ & BG11 and $F$ & $25^{\circ} \mathrm{C}$ \\
\hline
\end{tabular}

${ }^{\mathrm{a}} \mathrm{F}$ medium for $\mathrm{CH} 2, \mathrm{BG} 11$ medium for the other strains. 
Table 10 Plan of the experiments for screening the four selected Chlorella strains outdoors

\begin{tabular}{lcccccc}
\hline Trial & Duration (days) & Culture system & Culture regime & $\begin{array}{c}\text { Light regime } \\
\text { and intensity }\end{array}$ & Culture medium & Temperature \\
\hline $\begin{array}{l}\text { 6. High temperature growth } \\
\text { in bubble tubes }\end{array}$ & 4 & $1 \mathrm{~L}$ bubble tubes & Batch & $\begin{array}{c}\text { Natural illumination } \\
\text { (July) }\end{array}$ & BG11 and F & Not controlled \\
$\begin{array}{l}\text { 7. High temperature growth } \\
\text { in GWP reactors }\end{array}$ & 4 & $10 \mathrm{~L}, 0.25 \mathrm{~m}^{2} \mathrm{GWP}-\|$ & Batch & $\begin{array}{c}\text { Natural illumination } \\
\text { (July - August) }\end{array}$ & BG11 and/or F & Not controlled \\
$\begin{array}{l}\text { 8. Starvation in GWP } \\
\text { reactors }\end{array}$ & 5 & $10 \mathrm{~L}, 0.25 \mathrm{~m}^{2} \mathrm{GWP}-\|$ & Batch & $\begin{array}{c}\text { Natural illumination } \\
\text { (September) }\end{array}$ & F & $\begin{array}{c}\text { Cooled when } \\
\text { above } 40^{\circ} \mathrm{C}\end{array}$ \\
\hline
\end{tabular}

GWP, Green Wall Panel.

initial cell concentration was $0.4 \mathrm{~g} \mathrm{~L}^{-1}$. The first outdoors trial (Table 10, trial 6), was performed in July to test productivity at high temperatures using $1 \mathrm{~L}, 60 \mathrm{~mm}$ in diameter bubble tubes immersed in a water bath, without temperature regulation, in batch regime. The trial was carried out in both BG11 and F media.

The following outdoor trials (Table 10, trials 7 and 8) were carried in GWP-II photobioreactors. These culture systems are made of a flexible low-density polyethylene culture chamber contained within a simple structure comprising a wooden base and a number of vertical metal uprights driven directly into the base $[69,75]$. The four GWP-II panels used in the experiments were placed vertically, facing north-south, and side by side in a single row. Each panel was $50 \mathrm{~cm}$ wide and $70 \mathrm{~cm}$ high. The culture was $50 \mathrm{~cm}$ high, $10 \mathrm{~L}$ in volume and had a surface exposed to direct radiation of $0.25 \mathrm{~m}^{2}$. For mixing, compressed air was bubbled at the bottom through a perforated plastic tube; the air-flow rate was $0.5 \mathrm{~L} \mathrm{~L}^{-1} \mathrm{~min}^{-1}$. $\mathrm{CO}_{2}$ was injected with gas diffusers via a valve regulated by a $\mathrm{pH}$ control system set at a value of 7.5. The first trials in the GWP-II (Table 10, trial 7), in batch regime, were performed in July - August, to test growth at high temperatures on the isolation medium of each strain or in parallel in BG11 and F medium; cooling was not activated. The second trial (5-day long) in the GWP-II (Table 10, trial 8) was carried out in September to test the culture behaviour under nitrogen starvation, in F medium, in batch regime. In this case the culture was cooled by circulating in a serpentine placed in the reactor cold water when the culture temperature exceeded $40^{\circ} \mathrm{C}$. GWP reactors were inoculated with cultures from $1 \mathrm{~L}$ bubble tubes kept outdoors in both trials 7 and 8 .

\section{Analytical methods}

Culture growth was estimated by biomass dry weight determination: an aliquot of the culture $(5 \mathrm{~mL})$ was diluted to $50 \mathrm{~mL}$ and filtered on $47 \mathrm{~mm}$ membranes with nominal porosity of $1.2 \mu \mathrm{m}$ (FILTER-LAB, Barcelona, Spain), which were then washed with deionized water $(30 \mathrm{~mL})$ and dried at $105^{\circ} \mathrm{C}$ until constant weight. For cultures grown in laboratory under light:dark cycles and outdoors, the samples for determination of culture dry weight were collected at the end of the dark period.

For biomass composition analyses, the cultures were harvested by centrifugation and washed twice in $\mathrm{NaCl}$ solution at $1 \mathrm{~g} \mathrm{~L}^{-1}$ for cultures in BG11 and at $9 \mathrm{~g} \mathrm{~L}^{-1}$ for cultures in $\mathrm{F}$, and centrifuged again. The pellets were frozen and then lyophilized. The biomasses were analyzed for protein [76], carbohydrate [77] and lipid [78]. Ashes were determined using a muffle furnace on about $10 \mathrm{mg}$ of biomass (dry weight). Nitrogen $\left(\mathrm{N}-\mathrm{NO}_{3}^{-}\right)$concentration in the medium of nitrogen starved cultures was determined daily, using the method of Ferree and Shannon [79].

Solar radiation data obtained from the Photovoltaic Geographical Information System (PVGIS) were used for calculations reported in Table 7. The monthly average horizontal radiation $(\mathrm{Gh})$ and the ratio of diffuse (Dh) to global radiation ( $\mathrm{Dh} / \mathrm{Gh}$ ) were used to derive beam and diffuse average values on the horizontal for the period considered.

Beam radiation on the south-facing vertical panels was then calculated for each month following Kreith and Kreider [80]. Losses of beam radiation due to mutual shading were avoided as distance between panels was optimized for each month. Losses of diffuse radiation, with respect to an isolated reactor, which are a function of the slope of the reactor $(\beta)$ and the distance between panels (D), were calculated for each month considering a view factor $(\mathrm{Fd})$, representing the fraction of the sky dome viewed by vertical panels placed in parallel rows at a certain distance. A tilt factor for ground-reflected radiation (Rr), taking into account the ground area nonshaded by the panels, was finally calculated to account for the ground-reflected radiation intercepted by the vertical panels [80].

\section{Abbreviations}

$\beta$ : Slope of the reactor; D: Minimum distance between rows that avoids shading of direct radiation among the panels; Dh: Diffuse radiation on the horizontal; EPA: Eicosapentaenoic acid; Fd: View factor representing the fraction of the sky dome viewed by vertical panels placed in parallel rows at a certain distance; Gh: Global radiation on the horizontal; GWP: Green Wall Panel; PE: Photosynthetic efficiency; PVGIS: Photovoltaic geographical information system; Rr: Ground-reflected radiation. 


\section{Competing interests}

The authors declare that they have no competing interests.

\section{Authors' contributions}

AG carried out the cultivation of the strains, participated in the study design and drafted the manuscript. NBi participated in the study design and in the writing of the manuscript. GS participated in the cultivation of the strains and helped to draft the manuscript. LR participated in the study design and in the writing of the manuscript. NBa participated in the calculation of the productivity at 1 ha scale and in the writing of the manuscript. MRT conceived the study, coordinated and participated in the study design and in the writing of the manuscript. All authors read and approved the final manuscript.

\section{Acknowledgements}

The authors gratefully acknowledge Roquette Frères (Lestrem, France) and Fotosintetica \& Microbiologica S.r.l. (Florence, Italy) for the use of strains from their culture collections.

\section{Author details}

${ }^{1}$ Dipartimento di Scienze delle Produzioni Agroalimentari e dell'Ambiente Sezione di Microbiologia Agraria, Università degli Studi di Firenze, Piazzale delle Cascine 24, Firenze 50144, Italy. ${ }^{2}$ Fotosintetica \& Microbiologica S.r.l., Via dei Della Robbia 54, Firenze 50132, Italy.

\section{Received: 3 December 2013 Accepted: 6 May 2014}

Published: 7 June 2014

\section{References}

1. Spolaore P, Joannis-Cassan C, Duran E, Isambert A: Commercial applications of microalgae. J Biosci Bioeng 2006, 101:87-96.

2. Pulz O, Gross W: Valuable products from biotechnology of microalgae. Appl Microbiol Biotechnol 2004, 65:635-648.

3. Doucha J, Lívanský K: Production of high-density Chlorella culture grown in fermenters. J Appl Phycol 2012, 24:35-43.

4. Iwamoto $\mathrm{H}$ : Industrial production of microalgal cell-mass and secondary products-major industrial species. In Handbook of Microalgal Culture: Biotechnology and Applied Phycology. 1st edition. Edited by Richmond A. Oxford: Blackwell Publishing; 2004:255-263.

5. Pulz O, Broneske J, Waldeck P: IGV GmbH experience report, industrial production of microalgae under controlled conditions: innovative prospects. In Handbook of Microalgal Culture: Applied Phycology and Biotechnology. 2nd edition. Edited by Richmond A, Hu Q. Oxford: Wiley; 2013:445-460.

6. Huss VAR, Frank C, Hartmann EC, Hirmer M, Kloboucek A, Seidel BM, Wenzeler P, Kessler E: Biochemical taxonomy and molecular phylogeny of the genus Chlorella sensu lato (Chlorophyta). J Phycol 1999, 35:587-598.

7. Görs M, Schumann R, Hepperle D, Karsten U: Quality analysis of commercial Chlorella products used as dietary supplement in human nutrition. J Appl Phycol 2010, 22:265-276.

8. Hibberd DJ: Notes on the taxonomy and nomenclature of the algal classes Eustigmatophyceae and Tribophyceae (synonym Xanthophyceae). Bot J Linn Soc 1981, 82:93-119.

9. Becker EW: Micro-algae as a source of protein. Biotechnol Adv 2007, 25:207-210.

10. Liu J, Hu Q: Chlorella: industrial production of cell mass and chemicals. In Handbook of Microalgal Culture: Applied Phycology and Biotechnology. 2nd edition. Edited by Richmond A, Hu Q. Oxford: Wiley; 2013:329-338.

11. Chacón-Lee TL, González-Mariño GE: Microalgae for "healthy" foods possibilities and challenges. Compr Rev Food Sci Food Saf 2010, 9:655-675.

12. Petkov G, Garcia G: Which are fatty acids of the green alga Chlorella? Biochem Syst Ecol 2007, 35:281-285.

13. $W u Z Y, Q u C B$, Shi XM: Biochemical system analysis of lutein production by heterotrophic Chlorella pyrenoidosa in a fermentor. Food Technol Biotechnol 2009, 47:450-455.

14. Cho S, Cho S, Fahey GC: Generally Recognized As Safe (GRAS) Notice 000396. Clarksville, MD: NutraSource; 2011 [http://www.accessdata.fda.gov/scripts/ fcn/gras_notices/grn000396.pdf]

15. Commission E: Novel Food Catalogue. Brussels: European Commission; 2014 [http://ec.europa.eu/food/food/biotechnology/novelfood/nfnetweb/ mod_search/index.cfm]
16. Spoehr HA: Chlorella as a source of food. Proc Am Philos Soc 1951, 95:62-67.

17. Bishop WR, Zubeck HM: Evaluation of microalgae for use as nutraceuticals and nutritional supplements. J Nutr Food 2012, 2:5.

18. Becker EW: Microalgae Biotechnology and Microbiology. Cambridge: Cambridge University Press; 1994.

19. Becker W: Microalgae in human and animal nutrition. In Handbook of Microalgal Culture: Biotechnology and Applied Phycology. 1st edition. Edited by Richmond A. Oxford: Blackwell Publishing; 2004:312-351.

20. Gouveia L, Batista AP, Miranda A, Empis J, Raymundo A: Chlorella vulgaris biomass used as colouring source in traditional butter cookies. Innovative Food Sci Emerg Technol 2007, 8:433-436.

21. Beheshtipour H, Mortazavian A, Haratian P, Darani K: Effects of Chlorella vulgaris and Arthrospira platensis addition on viability of probiotic bacteria in yogurt and its biochemical properties. Eur Food Res Technol 2012, 235:719-728.

22. Beheshtipour H, Mortazavian AM, Mohammadi R, Sohrabvandi S, KhosraviDarani K: Supplementation of Spirulina platensis and Chlorella vulgaris algae into probiotic fermented milks. Compr Rev Food Sci Food Saf 2013, 12:144-154.

23. Fradique M, Batista AP, Cristiana Nunes M, Gouveia L, Bandarra NM, Raymundo A: Incorporation of Chlorella vulgaris and Spirulina maxima biomass in pasta products. Part 1: Preparation and evaluation. J Sci Food Agric 2010, 90:1656-1664.

24. Morris HJ, Almarales A, Carrillo O, Bermúdez RC: Utilisation of Chlorella vulgaris cell biomass for the production of enzymatic protein hydrolysates. Bioresour Technol 2008, 99:7723-7729.

25. Draaisma RB, Wijfels RH, Slegers PM, Brentner LB, Roy A, Barbosa MJ: Food commodities from microalgae. Curr Opin Biotechnol 2013, 24:169-177.

26. Norsker NH, Barbosa MJ, Vermue MH, Wijffels RH: Microalgal production - a close look at the economics. Biotechnol Adv 2011, 29:24-27.

27. Wijffels RH, Barbosa MJ: An outlook on microalgal biofuels. Science 2010, 329:796-799.

28. Malcata FX: Microalgae and biofuels: a promising partnership? Trends Biotechnol 2011, 29:542-549.

29. Hirano A, Ueda R, Hirayama S, Ogushi Y: $\mathrm{CO}_{2}$ fixation and ethanol production with microalgal photosynthesis and intracellular anaerobic fermentation. Energy 1997, 22:137-142.

30. Maršálková B, Širmerová M, Kuřec M, Brányik T, Brányiková I, Melzoch K Zachleder V: Microalgae Chlorella sp. as an alternative source of fermentable sugars. Chem Eng Trans 2010, 21:1279-1284.

31. Feng PZ, Deng ZY, Hu ZY, Fan L: Lipid accumulation and growth of Chlorella zofingiensis in flat plate photobioreactors outdoors. Bioresour Technol 2011, 102:10577-10584.

32. Münkel R, Schmid-Staiger U, Werner A, Hirth T: Optimization of outdoor cultivation in flat panel airlift reactors for lipid production by Chlorella vulgaris. Biotechnol Bioeng 2013, 110:2882-2893.

33. Moheimani NR: Long-term outdoor growth and lipid productivity of Tetraselmis suecica, Dunaliella tertiolecta and Chlorella sp (Chlorophyta) in bag photobioreactors. J Appl Phycol 2013, 25:167-176.

34. Pribyl P, Cepák V, Zachleder V: Production of lipids in 10 strains of Chlorella and Parachlorella, and enhanced lipid productivity in Chlorella vulgaris. Appl Microbiol Biotechnol 2012, 94:549-561.

35. Brányiková I, Maršálková B, Doucha J, Brányik T, Bišová K, Zachleder V, Vítová $\mathrm{M}$ : Microalgae - novel highly efficient starch producers. Biotechnol Bioeng 2011, 108:766-776.

36. Brennan $L$, Owende P: Biofuels from microalgae - a review of technologies for production, processing, and extractions of biofuels and co-products. Renew Sust Energy Rev 2010, 14:557-577.

37. Mata TM, Martins AA, Caetano NS: Microalgae for biodiesel production and other applications: a review. Renew Sust Energy Rev 2010, 14:217-232

38. Wijffels RH, Barbosa MJ, Eppink MHM: Microalgae for the production of bulk chemicals and biofuels. Biofuels, Bioprod Biorefin 2010, 4:287-295.

39. Li Y, Horsman M, Wu N, Lan CQ, Dubois-Calero N: Biofuels from microalgae. Biotechnol Prog 2008, 24:815-820.

40. Prommuak C, Pavasant P, Quitain AT, Goto M, Shotipruk A: Simultaneous production of biodiesel and free lutein from Chlorella vulgaris. Chem Eng Technol 2013, 36:733-739.

41. Subhadra B, Grinson G: Algal biorefinery-based industry: an approach to address fuel and food insecurity for a carbon-smart world. J Sci Food Agric 2011, 91:2-13. 
42. Parmar A, Singh NK, Pandey A, Gnansounou E, Madamwar D: Cyanobacteria and microalgae: a positive prospect for biofuels. Bioresour Technol 2011, 102:10163-10172.

43. Rodolfi L, Chini Zittelli G, Bassi N, Padovani G, Biondi N, Bonini G, Tredici MR: Microalgae for oil: strain selection, induction of lipid synthesis and outdoor mass cultivation in a low-cost photobioreactor. Biotechnol Bioeng 2009, 102:100-112.

44. Chini Zittelli G, Rodolfi L, Bassi N, Biondi N, Tredici MR: Photobioreactors for microalgal biofuel production. In Algae for Biofuels and Energy. Edited by Borowitzka MA, Moheimani NR. Dordrecht: Springer; 2013:115-131.

45. Chini Zittelli G, Biondi N, Rodolfi L, Tredici MR: Photobioreactors for mass production of microalgae. In Handbook of Microalgal Culture: Applied Phycology and Biotechnology. 2nd edition. Edited by Richmond A, Hu Q. Oxford: Wiley; 2013:225-266.

46. Borowitzka MA, Moheimani NR: Sustainable biofuels from algae. Mitig Adapt Strateg Glob Change 2013, 18:13-25.

47. Jorquera O, Kiperstok A, Sales EA, Embirucu M, Ghirardi ML: Comparative energy life-cycle analyses of microalgal biomass production in open ponds and photobioreactors. Bioresour Technol 2010, 101:1406-1413.

48. Biondi N, Bassi N, Chini Zittelli G, De Faveri D, Giovannini A, Rodolfi L, Allev C, Macrì C, Tredici MR: Nannochloropsis sp. F\&M-M24: oil production, effect of mixing on productivity and growth in an industrial wastewater. Environ Prog Sustainable Energy 2013, 32:846-853.

49. Hanagata N, Takeuchi T, Fukuju Y, Barnes DJ, Karube I: Tolerance of microalgae to high $\mathrm{CO}_{2}$ and high temperature. Phytochemistry 1992, 31:3345-3348

50. Béchet Q, Muñoz R, Shilton A, Guieysse B: Outdoor cultivation of temperature-tolerant Chlorella sorokiniana in a column photobioreactor under low power-input. Biotechnol Bioeng 2013, 110:118-126.

51. Tredici MR, Chini Zittelli G, Rodolfi L: Photobioreactors. In Encyclopedia of Industrial Biotechnology. Edited by Flickinger MC, Anderson S. New York, NY: John Wiley \& Sons; 2010:1-15.

52. Ong SC, Kao CY, Chiu SY, Tsai MT, Lin CS: Characterization of the thermal-tolerant mutants of Chlorella sp. with high growth rate and application in outdoor photobioreactor cultivation. Bioresour Technol 2010, 101:2880-2883.

53. de-Bashan LE, Trejo A, Huss VAR, Hernandez JP, Bashan Y: Chlorella sorokiniana UTEX 2805, a heat and intense, sunlight-tolerant microalga with potential for removing ammonium from wastewater. Bioresour Technol 2008, 99:4980-4989.

54. Morita M, Watanabe $Y$, Saiki H: High photosynthetic productivity of green microalga Chlorella sorokiniana. Appl Biochem Biotechnol 2000, 87:203-218.

55. Han F, Wang W, Li Y, Shen G, Wan M, Wang J: Changes of biomass, lipid content and fatty acids composition under a light-dark cyclic culture of Chlorella pyrenoidosa in response to different temperature. Bioresour Technol 2013, 132:182-189.

56. Bondioli P, Della Bella L, Rivolta G, Chini Zittelli G, Bassi N, Rodolfi L, Casini D, Prussi M, Chiaramonti D, Tredici MR: Oil production by the marine microalgae Nannochloropsis sp. F\&M-M24 and Tetraselmis suecica F\&M-M33. Bioresour Technol 2012, 114:567-572.

57. Recht L, Zarka A, Boussiba S: Patterns of carbohydrate and fatty acid changes under nitrogen starvation in the microalgae Haematococcus pluvialis. Appl Biochem Biotechnol 2012, 94:1495-1503.

58. Spoehr HA, Milner HW: The chemical composition of Chlorella; effect of environmental conditions. Plant Physiol 1949, 24:120-149.

59. Ho SH, Chen CY, Chang JS: Effect of light intensity and nitrogen starvation on $\mathrm{CO}_{2}$ fixation and lipid/carbohydrate production of an indigenous microalga Scenedesmus obliquus CNW-N. Bioresour Technol 2012, 113:244-252.

60. Dragone G, Fernandes BD, Abreu AP, Vicente AA, Teixeira JA: Nutrient limitation as a strategy for increasing starch accumulation in microalgae. Appl Energy 2011, 88:3331-3335.

61. Hu Q, Sommerfeld M, Jarvis E, Ghirardi M, Posewitz M, Seibert M, Darzins A: Microalgal triacylglycerols as feedstocks for biofuel production: perspectives and advances. Plant J 2008, 54:621-639.

62. Yeh KL, Chang JS: Effects of cultivation conditions and media composition on cell growth and lipid productivity of indigenous microalga Chlorella vulgaris ESP-31. Bioresour Technol 2012, 105:120-127.

63. Illman AM, Scragg AH, Shales SW: Increase in Chlorella strains calorific values when grown in low nitrogen medium. Enzyme Microb Technol 2000, 27:631-635.
64. Xu H, Miao XL, Wu QY: High quality biodiesel production from a microalga Chlorella protothecoides by heterotrophic growth in fermenters. J Biotechnol 2006, 126:499-507.

65. Stephenson AL, Dennis JS, Howe CJ, Scott SA, Smith AG: Influence of nitrogen-limitation regime on the production by Chlorella vulgaris of lipids for biodiesel feedstocks. Biofuels 2009, 1:47-58.

66. Miao XL, Wu QY: Biodiesel production from heterotrophic microalgal oil. Bioresour Technol 2006, 97:841-846.

67. Li XF, Xu H, Wu QY: Large-scale biodiesel production from microalga Chlorella protothecoides through heterotrophic cultivation in bioreactors. Biotechnol Bioeng 2007, 98:764-771.

68. Zhou XP, Xia L, Ge HM, Zhang DL, Hu CX: Feasibility of biodiesel production by microalgae Chlorella sp. (FACHB-1748) under outdoor conditions. Bioresour Technol 2013, 138:131-135

69. Tredici MR, Rodolfi L, Sampietro G, Bassi N: Low-cost photobioreactors for microalgae cultivation. 2011, Patent WO2011/013104 (to Fotosintetica \& Microbiologica)

70. Huang G, Chen F, Wei D, Zhang X, Chen G: Biodiesel production by microalgal biotechnology. App/ Energy 2010, 87:38-46.

71. Richardson JW, Johnson MD, Outlaw JL: Economic comparison of open pond raceways to photo bio-reactors for profitable production of algae for transportation fuels in the Southwest. Algal Res 2012, 1:93-100.

72. Tredici MR: Photobiology of microalgae mass cultures. Biofuels 2010, $1: 143-162$.

73. Rippka R, Deruelles J, Waterbury JB, Herdman M, Stanier RY: Generic assignments, strain histories, and properties of pure cultures of cyanobacteria. J Gen Microbiol 1979, 111:1-61.

74. Guillard RRL, Ryther JH: Studies of marine planktonic diatoms: I. Cyclotella nana Hustedt, and Detonula confervacea (Cleve) Gran. Can J Microbiol 1962, 8:229-239.

75. Tredici MR, Rodolfi L: Reactor for industrial culture of photosynthetic micro-organisms. Patent 2004, WO2004/074423 (to Università degli Studi di Firenze).

76. Lowry OH, Rosebrough NJ, Farr AL, Randall RJ: Protein measurement with the Folin phenol reagent. J Biol Chem 1951, 193:265-275.

77. Dubois M, Gilles K, Hamilton JK, Rebers PA, Smith F: A colorimetric method for the determination of sugars and related substances. Anal Chem 1956 , 168:167.

78. Marsh JB, Weinstein DB: Simple charring method for determination of lipids. J Lipid Res 1966, 7:574-576

79. Ferree MA, Shannon RD: Evaluation of a second derivative UV/visible spectroscopy technique for nitrate and total nitrogen analysis of wastewater samples. Water Res 2001, 35:327-332.

80. Kreith F, Kreider JF: Principles of Solar Engineering. Washington, DC: Hemisphere Publishing Corporation; 1978:37-82.

doi:10.1186/1754-6834-7-84

Cite this article as: Guccione et al.: Chlorella for protein and biofuels: from strain selection to outdoor cultivation in a Green Wall Panel photobioreactor. Biotechnology for Biofuels 2014 7:84.

\section{Submit your next manuscript to BioMed Central and take full advantage of:}

- Convenient online submission

- Thorough peer review

- No space constraints or color figure charges

- Immediate publication on acceptance

- Inclusion in PubMed, CAS, Scopus and Google Scholar

- Research which is freely available for redistribution 